\title{
STUDYING THE PERFORMANCE OF A HYDROTREATING PROCESS FOR A MIXTURE OF GAS OIL AND LIGHTER FRACTIONS
}

\author{
Mohammad F. Abid, \\ Department of Chemical Engineering, University of Technology, Baghdad, Iraq. \\ E-mail: 80005@uotechnology.edu.iq \\ Waleed H. Abohameed, \\ Department of Chemical Engineering, University of Technology, Baghdad, Iraq. \\ E-mail: wa.code1991@gmail.com
}

Shakir M. Ahmed,

SCOP, Ministry of Oil, Baghdad, Iraq.

E-mail: shakir58scop@gmail.com

Salah M. Ali,

Petroleum Research and Development Center, Ministry of Oil, Baghdad, Iraq.

E-mail: salah56ali@yahoo.com

Saad Kareem Ibrahim,

Petroleum Research and Development Center, Ministry of Oil, Baghdad, Iraq.

E-mail: refoil.2005@gmail.com

Received on 29 August 2017 Accepted on 31 October 2017 Published on 15 January 2018

DOI: $10.30772 /$ qjes.v10i4.494

\begin{abstract}
In the present study the applicability of hydrodesulfurization of a mixture of crude oil fractions (e.g., naphtha, kerosene, and gas oil) in a single hydrotreating reactor packed with NiCoMo/Al2O3 under various operating parameters such as temperature (310-370 oC), pressure (40-55 bars), weight hour space velocity (1.2 to $3.6 h-1)$, and hydrogen-to- liquid hydrocarbon ratio (150-300 vol/vol). Experimental results showed that temperature and pressure have a positive effect on process performance while weight hour space velocity gives a different trend. The optimum value of (H2/Hydrocarbon) ratio was found experimentally to be $200 \mathrm{vol} / \mathrm{vol}$ after which the increase in this ratio cause
\end{abstract}


reduction in HDS\% because decrease in contact between $\mathrm{H} 2$ gas and Hydrocarbon in reactor. Results showed that the best conditions (350 oC, 50 bars, 1.2 h-1, and 200 $\mathrm{vol} / \mathrm{vol}$ ) in which gave the hydrotreating (HDS) efficiency of $95.8 \%$. The results confirmed the applicability of the NiCoMo/Al2O3 catalyst for HDS reaction of a mixture of middle distillate (e.g., naphtha, kerosene, and gas oil). It was found that at higher pressure and temperature (i.e., T> 350 oC; $P>50$ bars) a thermodynamic equilibrium was established. As observed, there is a $1.6 \%$ reduction in gas oil less than that of the conventional method. However, kerosene, heavy naphtha, and light naphtha undergo increases of $0.6 \%, 0.75 \%$, and $2.75 \%$ respectively over these from conventional method. These results reveal that the quantity of fractions is almost the same for both methods. As it can be observed, that measured properties of the oil fractions produced by the proposed method are almost the same as those produced by conventional method. However, specific gravity (sp.gr) of the oil cuts produced by present study (i.e. sp.gr of kerosene, heavy naphtha, and light naphtha $0.785,0.728,0.655$ respectively) is somewhat less than sp.gr of the same fractions produced by conventional methods (i.e. sp.gr of kerosene, heavy naphtha, and light naphtha 0.788, 0.738, 0.65 respectively), which gives a clear indication of properties improvement of these fractions. Experimental results confirmed the applicability of the proposed method for HDS of a mixture of Iraqi middle distillates (i.e., naphtha, kerosene, and gas oil) simultaneously in a single fixed bed reactor.

Keywords: hydrotreating, Mixture of crude oil fractions, NiCoMo/Al2O3 catayst

\section{NOMENCLATURE}

$\begin{array}{ll}\text { API } & \text { American Petroleum Institute } \\ \text { EP } & \text { End Point of boiling point, }{ }^{\circ} \mathrm{C} \\ \text { GOL } & \text { Gas Oil and Light fraction } \\ \text { HDS } & \text { Hydrodesulfurization } \\ \text { HDT } & \text { Hydrotreating } \\ \text { HN } & \text { Heavy Naphtha } \\ \text { HTR } & \text { Hydrotreating Reactor } \\ \text { IBP } & \text { Initial Boiling Point, }{ }^{\circ} \mathrm{C} \\ \text { MHC } & \text { Mild Hydrocracking } \\ \text { LN } & \text { Light Naphtha } \\ \text { LPG } & \text { liquefied petroleum gas } \\ \text { LGO } & \text { Light Gas Oil } \\ \text { P } & \text { Pressure, bar } \\ \text { PR\&D } & \text { Petroleum research \& development } \\ \text { RCR } & \text { Reduced Crude Oil } \\ \text { S } & \text { weight content of sulfur in feed }\end{array}$




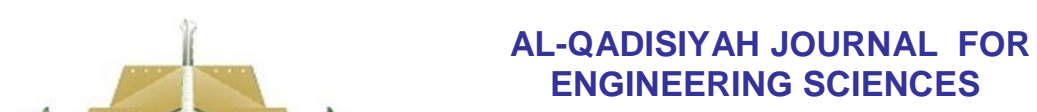

Vol. 10 , No. 4

ISSN: 1998-4456

$\mathrm{S}_{\mathrm{p}}$

Sp.gr

T

WHSV weight content of sulfur in product

Specific gravity of oil

Temperature, ${ }^{\circ} \mathrm{C}$

Weight Hour Space Velocity, $\mathrm{h}^{-1}$

\section{INTRODUCTION}

In a modern petroleum refinery, the HDT process includes a complex and sophisticated system due to a large number of reactors, vessels, controlling system with different operating variables (temperatures, pressure, LHSV and $\mathrm{H} 2$ to oil ratio) for each reactor. Many technical problems have evolved from this sophisticated system. Furthermore, high fixed capital cost is usually invested in this complex system. Simplification of such system is one of the main goals of all engineers of the field. Published data on HDT of a mixture of middle distillates in one time in a single HDT reactor are scarce.

Crude oil is complex mixture of various hydrocarbon compounds with different heteroatoms such as $\mathrm{S}, \mathrm{N}_{2}, \mathrm{O}_{2}$ and some metals ( $\mathrm{Ni}$ and $\mathrm{V}$ ). Marketplace requests for different crude oil products are high. The typical consumption of different fuels (i.e. Gasoline, Kerosene, Jet fuels, etc.) is equal to $40-50 \%$ of crude oil consumption and the worldwide consumption will rise in the next years so, it is necessary to growth distillate production at high quality. To meet these challenges, a lot of efforts have been committed and a number of oil upgrading machineries have been developed by leading petroleum research institutions. Catalytic hydroprocessing seems to be a promising technology for upgrading of heavy oils (SPEIGHT,2010).

(Heinrich and Kasztelan 2001) analyzed various fractions, of a crude oil originally having a 1.2 wt.\% sulfur, for sulfur content. They indicated that sulfur compounds tend to concentrate in the heavier fractions of oil, as shown in Table (1).

Table (1): Distribution of sulphur compounds in the various fractions of a crude oil originally having a $1.2 \%$ content in weight of sulphur (Heinrich and Kasztelan, 2001).

\begin{tabular}{|c|c|c|c|c|c|c|}
\hline \multirow[t]{2}{*}{ Fraction } & \multirow{2}{*}{$\begin{array}{c}\text { Distillation } \\
\text { interval } \\
\left({ }^{\circ} \mathrm{C}\right)\end{array}$} & \multirow{2}{*}{$\begin{array}{l}\text { Sulphur } \\
\text { Wt. (\%) }\end{array}$} & \multicolumn{2}{|r|}{ Sulphur } & compounds & (Wt.\%) \\
\hline & & & Mercaptans & Sulphides & Thiophenes & $\begin{array}{l}\text { Benzo thiophenes and } \\
\text { Heavy Sulphides }\end{array}$ \\
\hline Gasoline & $70-180$ & 0.02 & 50 & 50 & traces & -- \\
\hline Kerosene & $160-240$ & 0.2 & 25 & 25 & 35 & 15 \\
\hline Gas oil & $230-350$ & 0.9 & 15 & 15 & 35 & 35 \\
\hline $\begin{array}{l}\text { Vacuum } \\
\text { gas oil }\end{array}$ & $350-550$ & 1.8 & 5 & 5 & 30 & 55 \\
\hline residue & $>550$ & 2.9 & Traces & Traces & 10 & 90 \\
\hline
\end{tabular}

The influence of sulfur content on the performance of $\mathrm{CoMo} / \mathrm{Al}_{2} \mathrm{O}_{3}$ hydrotreating catalyst was inspected by (Rana et al., 2004) using different model reactants in a batch reactor at $4 \mathrm{MPa}$ and $340^{\circ} \mathrm{C}$. The effect of sulfur (0-2 wt.\%) content was studied by varying the loadings of DBT. Authors indicated opposite effects of the produced $\mathrm{H}_{2} \mathrm{~S}$ on selectivity. A slurry batch reactor was utilized by (Deng et al. 2010) to study HDS of diesel fuel at different operating conditions (Pressure $=3-5 \mathrm{MPa}$, Temperature $=320-360{ }^{\circ} \mathrm{C}$, and hydrogen flow rate up to $2.8 \mathrm{~L}^{*} \mathrm{~min}^{-1}$ ). The catalyst used was $\mathrm{NiMo} / \mathrm{Al}_{2} \mathrm{O}_{3}$ with loading $4-23 \mathrm{wt} . \%$. The authors concluded that the reaction rate increased as temperature, pressure, and flow of hydrogen. The catalyst loading was found to have a positive effect on reaction rate.

(Farag ,2012) investigated the catalytic performances of unsupported catalysts of the hydrodesulfurization process for sulfur removal from gas oil and compared the result with the result that obtain from a supported catalyst. The hydrodesulfurization reactions were carried out in a batch reactor when the temperature and pressure equal to $340{ }^{\circ} \mathrm{C}$ and $3 \mathrm{MPa}$, respectively. Authors reported that the 


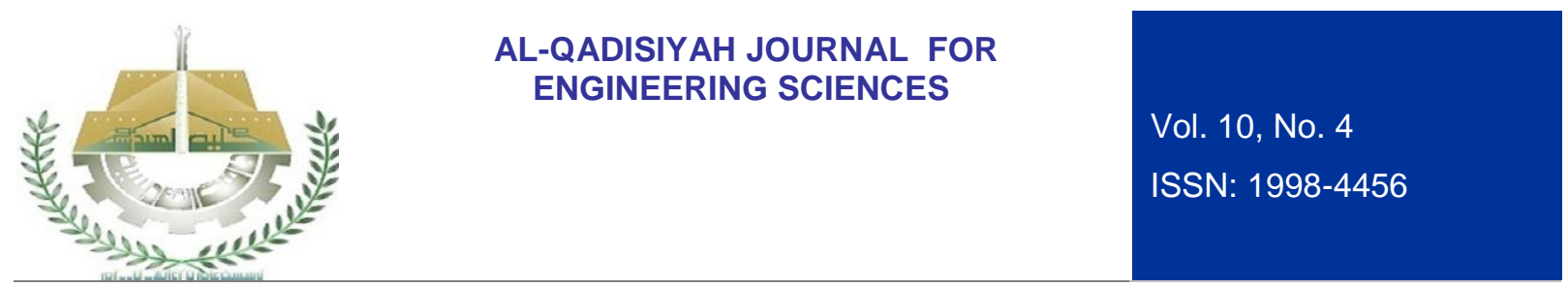

unsupported catalyst operate at high activity and the sulfur reduce into less than 10 ppm (Liu and Zou 2013) studied experimentally the influence of aromatics addition on the hydrotreating (HDT) of oil residue. Authors reported that the addition of aromatics enhanced the removal of heteroatoms and metals from oil residue. Ferreria et al. (2014) investigated the effect of different feeds of crude oil (Arabian Light, Buzurgan, and Ural) on the reactions of hydrodesulfurization (HDS) and hydrodemetalization (HDM) under industrial conditions using commercial catalysts. Authors reported that properties of the feed have pronounced effect on the HDT efficiency. CoNiMo catalysts with various content of promoters were used by (Klimov et al., 2016) for hydrodesulfurization of gas oil. Temperature equal to $390{ }^{\circ} \mathrm{C}$ and pressure equal to 90 bars were used to investigate the optimum proportions of active metals in the catalyst. Abid et al. (2017) studied the influence of $\mathrm{N}$ - species on hydrodesulfurization activity of SRHN loaded with $\mathrm{C} 4 \mathrm{H} 4 \mathrm{~S}$ compound, as a sulfidation agent, over CoMo/ $/ \mathrm{Al}_{2} \mathrm{O}_{3}$ in a fixed bed reactor at variable operating parameters (e.g., $\mathrm{T}=593-653 \mathrm{~K}, \mathrm{P}=20-$ $35 \mathrm{bar}$, weigh hour space velocity $=2.5-5 \mathrm{~h}^{-1}$, and $\left(\mathrm{H}_{2} / \mathrm{oil}\right)$ ratio $=60 \mathrm{vol} / \mathrm{vol}$. with various concentrations of carbazole and pyridine. Authors reported that conversion of sulfur increases as $T$ and $P$ increased. However the image of sulfur conversion with weight hour space velocity was different. Authors revealed that HDS efficiency was raised up in the following sequence: mixture of cabazole and pyridine < pyridine < carbazole.

Hydrotratment configuration of middle distillates in a modern petroleum refinery is characterized by severe operating conditions and sophisticated system which lead to high fixed and operating costs. Simplification of such system was the goal of every process and design engineers. Literature on hydrotrating of a mixture of middle distillates in a single hydrotrating reactor is scarce.

In present work the proposed HDT process could be simplified as gas oil and lighter fractions (naphtha and kerosene); these mixture volumetric quantities, as have been present in crude oil. The gas oil and lighter fractions are hydrodesulfurization all at once in one HRT reactor to reach the sulfur specification of each oil fractions. next HDS process, the reaction product is further separation into LPG, light naphtha, heavy naphtha, kerosene, and gas oil. Thus the expected benefits from the proposed HDT method is the reduction of number of HDT reactors from three to one with their utilities (i.e., feeding and intermediate vessels, pumps, control systems, and systems used for heating, cooling, and purging). Consequently, the fixed capital cost, and operational cost will be reduced.

The highest objective of present study to investigate the feasibility of hydrodesulfurization of a mixture of middle distillate (e.g., naphtha, kerosene, and gas oil) in a single hydrotrating reactor under various operating parameters (e.g., temperature, pressure, liquid flow rate, and $\left(\mathrm{H}_{2} /\right.$ oil) ratio. study for the quality and productivity of products was conducted a comparison between the proposed method and conventional one for HDS of middle distillates obtained from Al-Daura refinery/ Baghdad.

\section{MATRIALS AND METHODS}

\subsection{MATERIALS}

The commercial catalyst used was $\mathrm{CoNiMo} / \mathrm{y}-\mathrm{Al}_{2} \mathrm{O}_{3}$ whose properties are listed in Table (2). It was supplied from Al_Daura refinery/Baghdad. Gas oil and lighter fractions (mixture of Naphtha, Kerosene, and gas oil) was used as a real feed in all experiments for the HDS process was supplied from Al_Daura Refinery. Gas oil and lighter fractions were obtained as one cut after separation of LPG and residue from Basra medium crude oil at the atmospheric distillation column, Al-Dora refinery. The main properties of the feedstock (i.e. Gas oil and lighter fraction) used in this work is listed in Table (3). $\mathrm{H}_{2}$ gas (99.9 vol\%) and $\mathrm{N}_{2}$ (99 vol\%) gas were purchased from (Al_Mansoor Co., Iraq).

Table (2): Specification of Catalyst.

\begin{tabular}{|c|c|c|}
\hline Chemical specifications & Units & Value \\
\hline $\mathrm{MoO}_{3}$ & wt. \% & 17 \\
\hline $\mathrm{CoO}$ & wt. \% & 2.7 \\
\hline $\mathrm{NiO}$ & wt. \% & 0.9 \\
\hline $\mathrm{Al}_{2} \mathrm{O}_{3}$ & wt. \% & Balance \\
\hline
\end{tabular}




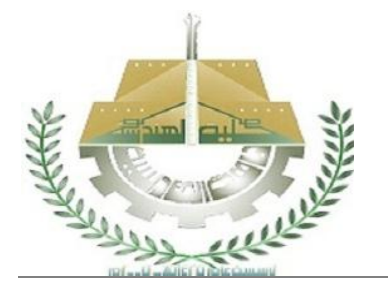

AL-QADISIYAH JOURNAL FOR ENGINEERING SCIENCES

Vol. 10, No. 4

ISSN: $1998-4456$

\begin{tabular}{|c|c|c|}
\hline \multicolumn{2}{|c|}{ Physical specifications } & 160 \\
\hline Surface area & $\mathrm{m}^{2} / \mathrm{g}$ & 0.43 \\
\hline Pore volume & $\mathrm{cm}^{3} / \mathrm{g}$ & 750 \\
\hline Bulk density & $\mathrm{kg} / \mathrm{m}^{3}$ & 1.6 \\
\hline Mean particle diameter & $\mathrm{Mm}$ & \\
\hline Shape & Extradite & \\
\hline
\end{tabular}

Table (3): Feedstock properties (i.e., gas oil and lighter fractions).

\begin{tabular}{|c|c|}
\hline Properties & Specification \\
\hline Initial boiling point & $30^{\circ} \mathrm{C}$ \\
\hline End boiling point & $330^{\circ} \mathrm{C}$ \\
\hline $\mathrm{API}$ & 45.37 \\
\hline Specific gravity & 0.80 \\
\hline Density at $15^{\circ} \mathrm{C}$ & $0.80 \mathrm{gm} . / \mathrm{cm}^{3}$ \\
\hline Sulfur content & $4341 \mathrm{ppm}$ \\
\hline $\begin{array}{l}\text { Distillate boiling point range }{ }^{\circ} \mathrm{C} \\
\text { Light naphtha B.P range }(30-122)^{\circ} \mathrm{C} \\
\text { Heavy naphtha B.P range }(80-180)^{\circ} \mathrm{C} \\
\text { Kerosene B.P range }(142-242)^{\circ} \mathrm{C} \\
\text { Gas oil B.P range }(200-322)^{\circ} \mathrm{C}\end{array}$ & $\begin{array}{l}\text { Vol. } \% \\
14.5 \text { Vol. } \% \\
24 \text { Vol. } \% \\
25 \text { Vol. } \% \\
36.5 \text { Vol. } \%\end{array}$ \\
\hline
\end{tabular}

\subsection{EXPERIMENTAL SETUP}

The hydrotreating experimental apparatus which has been located at the Petroleum Research and Development Center, seen in Figure (1), including a cylindrical reactor (I.D. $=17.5 \times \mathrm{L}=160 \mathrm{~mm}$ ) made of stainless steel and heated by box shape electrical heater. The system have been also provided with indicators to measure the temperature of inlet liquid feed, inlet gas, reaction chamber, and heating mantel of reactor. Middle distillates (i.e., gas oil and lighter fractions) were mixed in volumetric proportions, as have been produced from the atmospheric distillation unit of crude oil, and injected into the top of reactor by a dosing pump. The liquid middle distillates feed was preheated by an electric heater and mixed co-currently with hydrogen gas before it introduced into the top of reactor. The effluent from the bottom of reactor was sent to a cooler where reaction products condensed then sent to a high-pressure separator to separate gases (e.g., unreacted $\mathrm{H}_{2}, \mathrm{NH}_{3}$, and $\mathrm{H}_{2} \mathrm{~S}$ ) from liquid product which accumulated in a product tank and distillated in fractionation column to light naphtha, heavy naphtha, kerosene, and gas oil. The liquid feed and hydrogen gas were measured via calibrated digital flow meters installed on the feeding lines. 

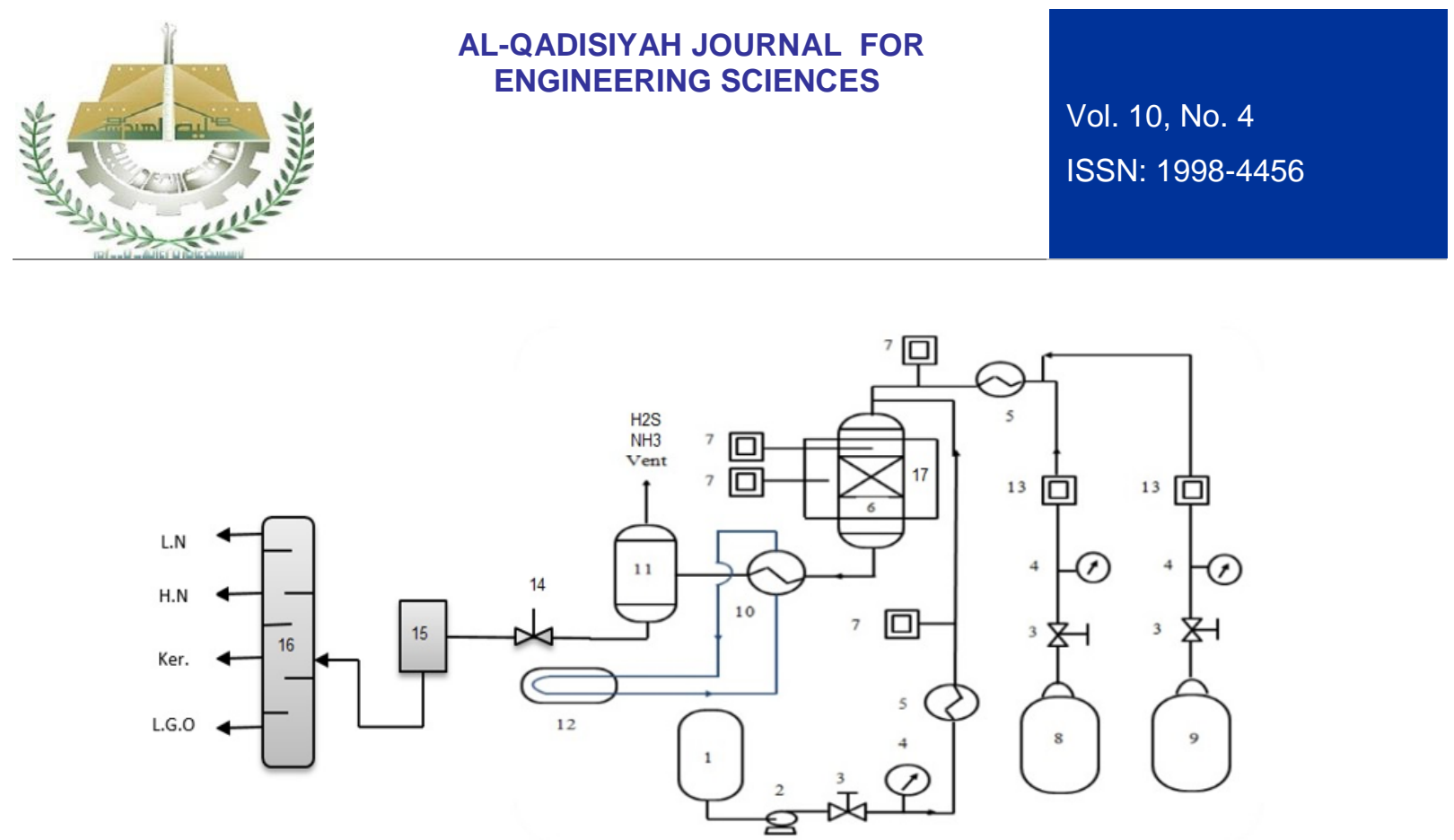

1-Liquid mixture vessel, 2-Pump, 3- stopcock, 4-Pressure indicator, 5-Heater, 6- Fixed-bed reactor 7-Temerature sensor, 8- High pressure H2 bottle, 9- High pressure N2 bottle, 10-Heat exchanger 11-Cooler, 12-Chiller 13-gas flow meter 14-throtte valve1 15-buffer tank 16- fractionation column 17- electric heater with temperature controller

Figure (1): Schematic of the HDS setup.

\subsection{EXPERIMENTAL PROCEDURE}

The experimental procedure of this work was carried out in the following sequence:

-Drying process of catalyst.

- Sulfiding process of catalyst.

-Investigate the effect of process variables on HDS efficiency of gas oil and lighter fractions.

-Investigate the effect of operating variables on the yield and product quality of liquid products (naphtha, kerosene and gas oil ).

\subsubsection{Drying process}

Table (4) lists the operating conditions of the drying process.

Table (4): operating conditions of the drying process.

\begin{tabular}{|c|c|}
\hline Operating conditions & Specification \\
\hline Temperature & $200{ }^{\circ} \mathrm{C}$ \\
\hline Pressure & $10 \mathrm{bar}$ \\
\hline $\mathrm{N}_{2}$ flow rate & $160 \mathrm{Nl} / \mathrm{hr}$ \\
\hline Time & $10 \mathrm{hr}$ \\
\hline
\end{tabular}

The moisture detected by measuring the output gas from the high pressure (H.P.) separator using moisture content measuring device (AP2-a100), the first sample was taken after two hours, the second sample was taken after ten hours of operation. When the moisture content of effluent gas was reached a value of (15 ppm), the drying process is considered completed (Manual instructions of Petroleum Research and Development Center). 


\section{AL-QADISIYAH JOURNAL FOR ENGINEERING SCIENCES}

\section{Vol. 10 , No. 4}

ISSN: $1998-4456$

\subsubsection{Sulfiding process}

In this process the catalyst was activated by converting $\left(\mathrm{CoNiMoO}_{4}\right)$ into $(\mathrm{CoNiMoS})$ form. In the present work, gas oil has been utilized for the sulfidation step with $\mathrm{H}_{2}$ gas. The concentration of sulfur in feeding stream was $(4945 \mathrm{ppm})$. Operating parameters of the sulfidation step were $\left(\mathrm{T}=200-300{ }^{\circ} \mathrm{C}, \mathrm{P}=15\right.$ bar, light gas oil flow $=120 \mathrm{ml} / \mathrm{hr},\left(\mathrm{H}_{2} / \mathrm{HC}\right)$ ratio $=200 \mathrm{vol} / \mathrm{vol}$, and time of sulfidation $\left.=19 \mathrm{hrs}\right)$. The operating instructions of the Petroleum Research and Development Center suggested that the sulfidation step is complete when a $0.05 \%$ increase in catalyst weight occurs. This increase in weight is attributed to the sulfur deposition over the catalyst surface. Experimentally, it is decided that the sulfidation step is completed when the concentration of sulfur in the outlet stream equals to that in the inlet. Figure (2a) and Figure (2b) show the sulfidation procedure and the change in sulfur concentration at the outlet stream during the sulfidation step, respectively.

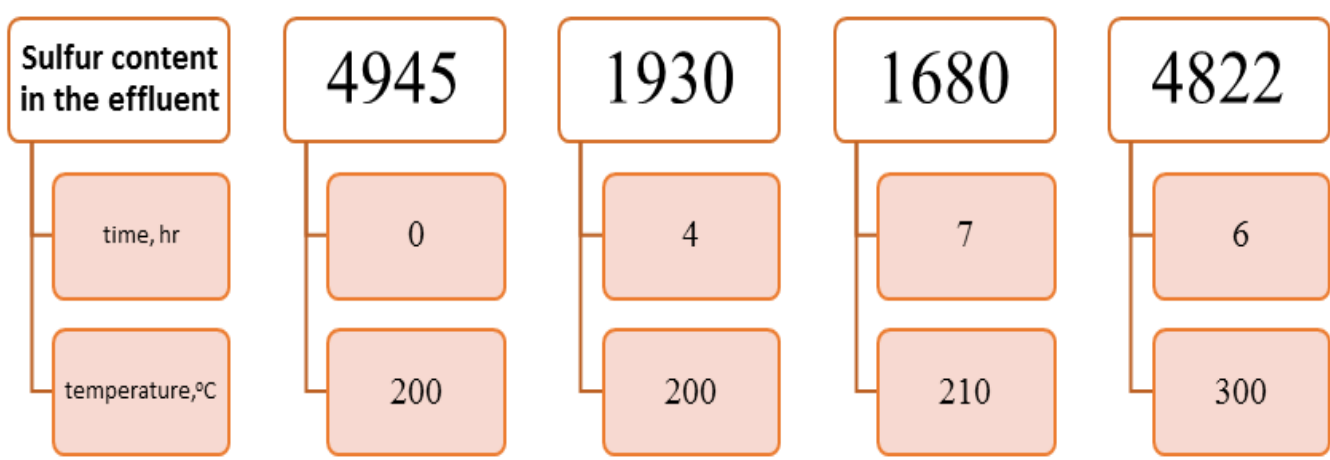

Figure (2a): Sulfiding process steps at $\left(P=15 \mathrm{bar}, \mathrm{T}=350^{\circ} \mathrm{C}\right.$, gas oil flow $=120 \mathrm{ml} / \mathrm{hr}$ and $\left.\mathrm{H} 2 / \mathrm{oil}=200\right)$.

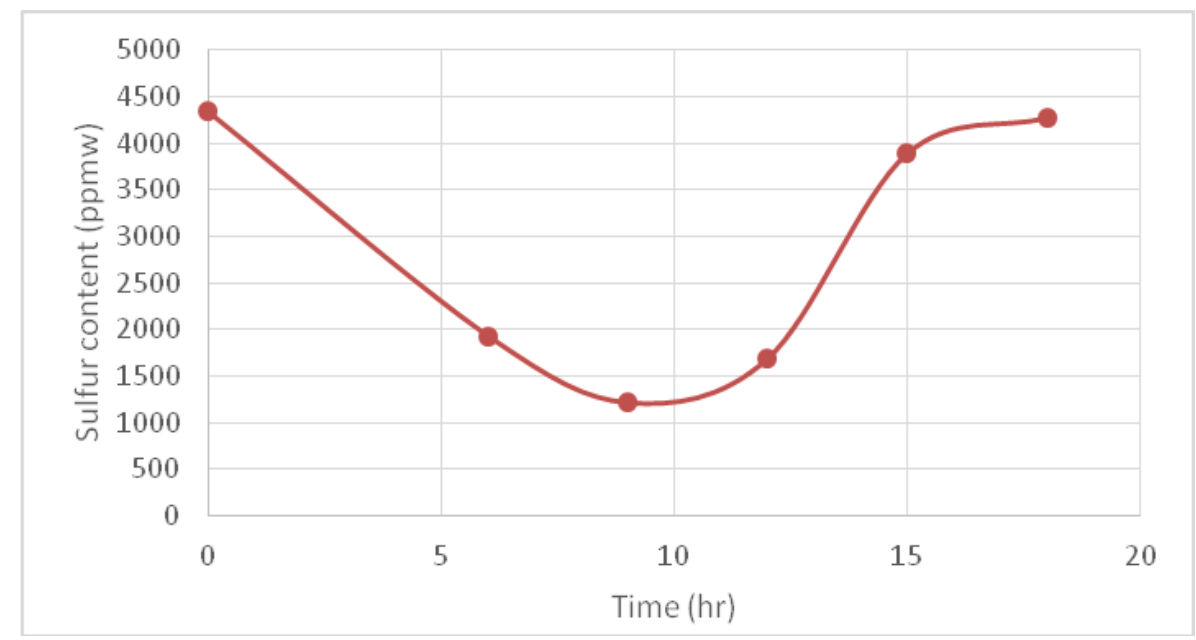

Figure (2b): Sulfur concentration in outlet stream as function of sulfidation time 


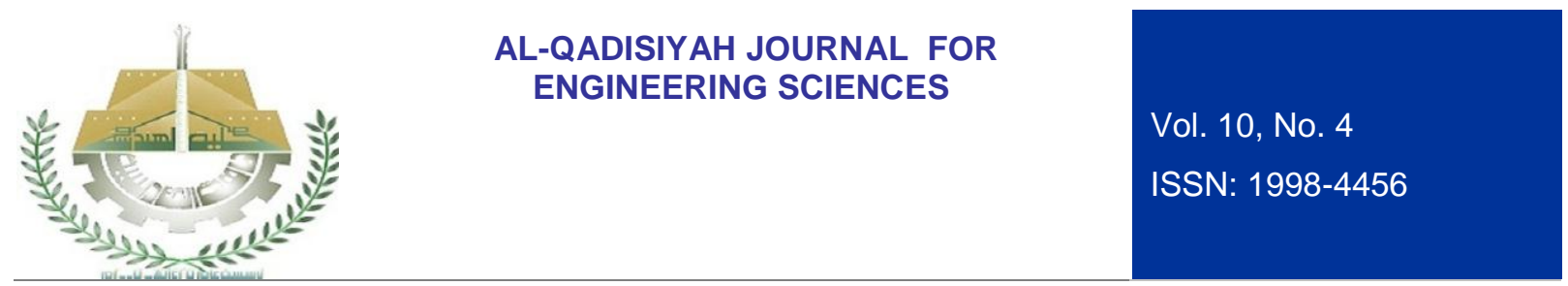

\subsubsection{Hydrotreating process steps:}

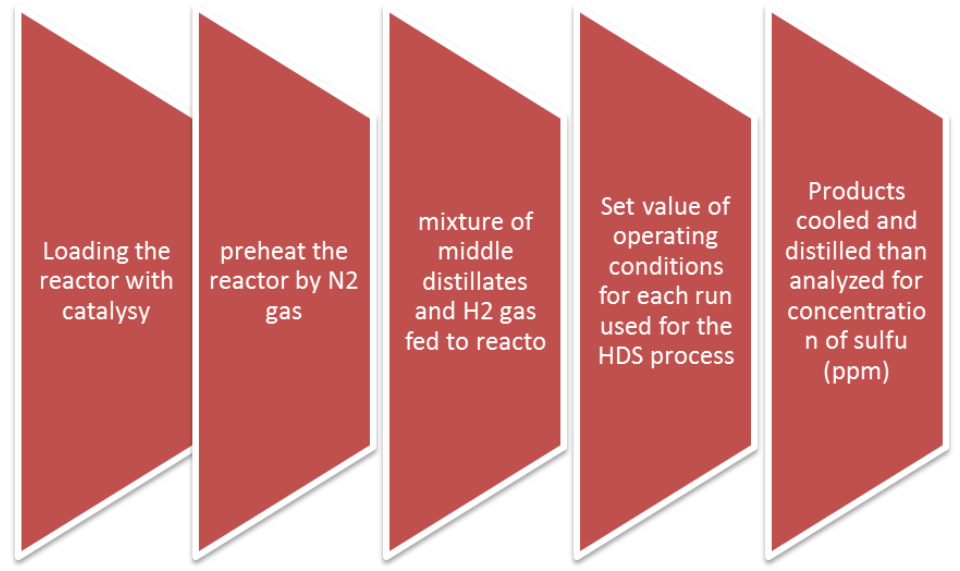

Figure (3): Experimentally Hydrotreating process steps.

Hydrotreating process for a mixture of gas oil and lighter fractions was conducted by:-

- Loading the reactor with $50 \mathrm{gm}$ of CoNiMo-S/Al2O3 depended on the selected values of WHSV within the range of the values used in the industry scale $(50 \mathrm{gm}$. of catalyst have the volume $66 \mathrm{ml}$ and the total volume of reactor $77 \mathrm{ml}$ the remain reactor volume was packed with inert particles (glass beads of $1 / 4 "$ diameter) at entrance and the bottom of reactor. This entrance section was employed to heat up the mixture to the required temperature and to ensure homogeneous flow distribution of gas and liquid.

- $\mathrm{N}_{2}$ gas was fed over one hour to heat the environment inside the reactor.

- Prepared mixture of middle distillates was charged at the desired flow into the reaction chamber. To start the HDS reaction, $\mathrm{H}_{2}$ gas was injected co-currently with the liquid mixture at the desired flow value.

- Reactor temperature starts to increase due to the heat liberated from the chemical reaction which controlled by the set value of the temperature controller that regulate the energy given by the heating elements of the box furnace.

- Set value of operating conditions for each run used for the HDS process were (Temperature $=310$ $370{ }^{\circ} \mathrm{C}$, WHSV $=1.2$ to $3.6 \mathrm{~h}^{-1}$, pressure $=40$ to $55 \mathrm{bar}$, and $(\mathrm{H} 2 / \mathrm{HC})$ ratio $=150$ to $\left.300 \mathrm{vol} / \mathrm{vol}\right)$.

- Products were cooled and distilled than analyzed for concentration of sulfur in each oil fractions.

- The efficiency of the HDS process was calculated from equation (1).

$$
H D S \%=\frac{(S f-S p)}{S f} * 100
$$

\subsection{ANALYSES TECHNIQUES}

Concentration of sulfur into inlet and outlet stream of reactor was measured using (XOS analyzer, model Sindie OTG, USA). Water moisture inside the reaction chamber during the drying step was measured using (Meeco analyzer, model WaterBoy 2, USA). 


\section{AL-QADISIYAH JOURNAL FOR ENGINEERING SCIENCES}

\section{Vol. 10, No. 4}

ISSN: $1998-4456$

\section{RESULTS AND DISCUSSION}

\subsection{INFLUENCE OF KEY PARAMETERS ON HDS \% FOR A MIXTURE OF HCS}

\subsubsection{Influence of $\left(\mathrm{H}_{2} / \mathrm{HC}\right)$ ratio}

Variation of HDS efficiency against $\left(\mathrm{H}_{2} / \mathrm{HC}\right)$ volumetric ratio for CoNiMo-S/Al $\mathrm{O}_{3}$ keeping other operating parameters unchanged at $\left(\mathrm{P}=45 \mathrm{bar}, \mathrm{T}=350{ }^{\circ} \mathrm{C}\right.$, WHSV $\left.=1.2 \mathrm{~h}^{-1}\right)$, Figure (4) is described variation of $\mathrm{HDS}$ against $\left(\mathrm{H}_{2} / \mathrm{HC}\right)$ as $\left(\mathrm{H}_{2} / \mathrm{HC}\right)$ volumetric ratio increased from 150 to $200 \mathrm{Nm}^{3} / \mathrm{m}^{3}$, HDS efficiency increased from 84 to $90 \%$ correspondingly. However, as $\left(\mathrm{H}_{2} / \mathrm{HC}\right)$ ratio increased from 200 to 300 $\mathrm{Nm}^{3} / \mathrm{m}^{3}$ efficiency of HDS descended from 90 to $88.5 \%$ because decrease the contact time between the $\mathrm{H} 2$ gas and liquid $\mathrm{HCS}$ since $\mathrm{H} 2$ will flow at high rate. This revealed that the sulfur conversion plateaus at $\left(\mathrm{H}_{2} / \mathrm{HC}\right)$ ratio $=200 \mathrm{Nm}^{3} / \mathrm{m}^{3}$ and a slight decrease for sulfur removal have been observed at higher $\mathrm{H}_{2} / \mathrm{HC}$ ratios.

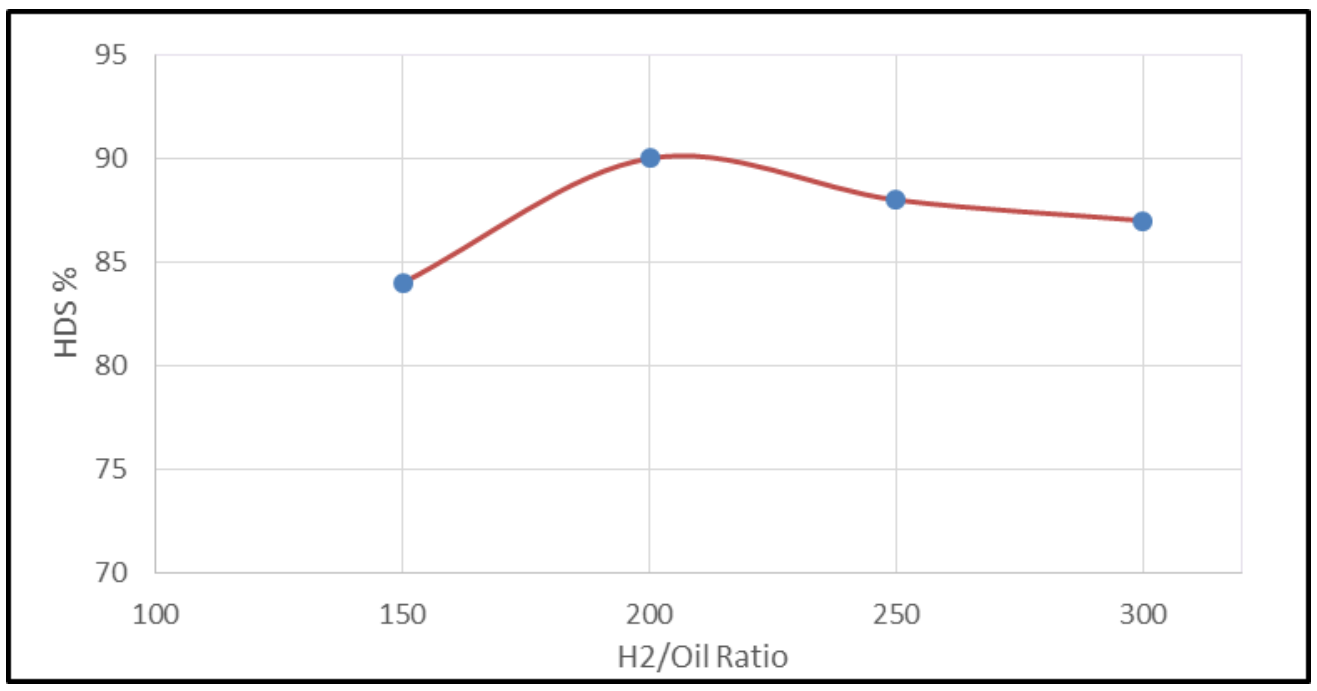

Figure (4): Effect of $\mathrm{H}_{2}$ - to- oil ratio on HDS efficiency for CoNiMo-S/ $\mathrm{Al}_{2} \mathrm{O}_{3}$ at $\left(\mathrm{P}=45\right.$ bar, $\mathrm{T}=350{ }^{\circ} \mathrm{C}$, WHSV $=$ $\left.1.2 \mathrm{~h}^{-1}\right)$.

Similar results to those above were observed by (Majak, 2010) and (Bej, 2001). They found that the $\mathrm{H} 2 / \mathrm{HC}$ ratio had an optimal value, depending upon the other process variables, after which a further increase in this ratio did not result in HDS improvement.

\subsubsection{Influence of temperature}

The influence of temperature on efficiency of HDS was investigated for CoNiMo/ $\mathrm{Al}_{2} \mathrm{O}_{3}$ catalyst at the temperature and WHSV ranges $310-370{ }^{\circ} \mathrm{C}$ and 1.2-3.6 $\mathrm{h}^{-1}$ respectively at 50 bar and $\left(\mathrm{H}_{2} / \mathrm{HC}\right)$ ratio of 200 $\mathrm{vol} / \mathrm{vol}$. Figure (5) shows the outcomes. 

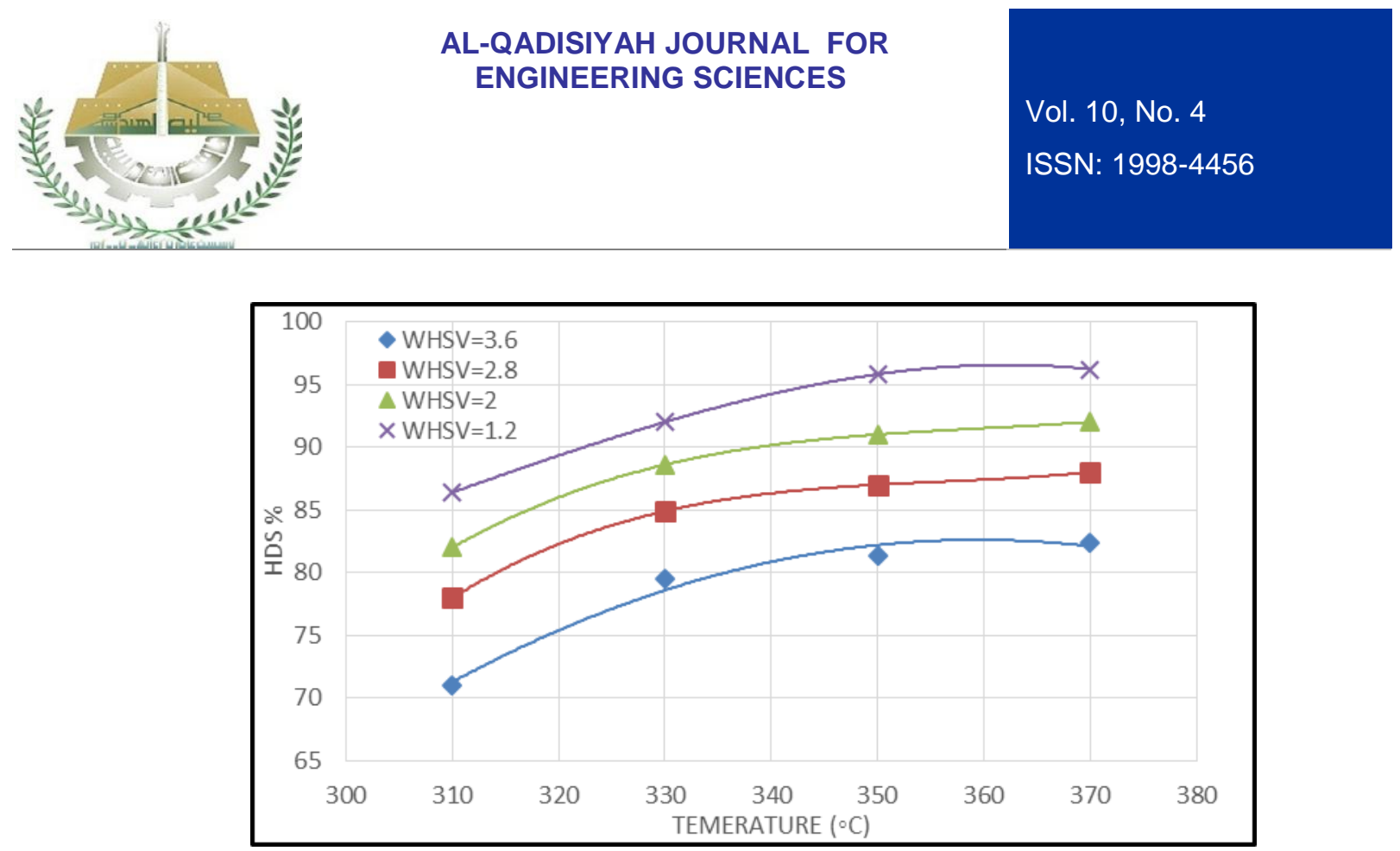

Figure (5): Influence of temperature on HDS efficiency of a mixture of HCs at different WHSV and constant $\left(\mathrm{P}=50\right.$ bars and $\mathrm{H}_{2}$-to- $\mathrm{HC}$ ratio $\left.=200 \mathrm{vol} / \mathrm{vol}\right)$ for $\mathrm{CoNiMo} / \mathrm{Al}_{2} \mathrm{O}_{3}$.

As can be observed, at constant pressure and $\left(\mathrm{H}_{2} / \mathrm{HC}\right)$ ratio, the HDS efficiency increased as temperature increased while WHSV gives a different trend. At constant WHSV $=1.2$, the HDS efficiency is $86.4,92,95.8$, and $96.2 \%$ when the temperature is $310,320,350$, and 370 respectively. This effect of temperature on HDS efficiency may be due to the positive relationship between operating temperature and the reaction rate constant as stated by Arrhenius equation. The increase in HDS efficiency is rapid up to a temperature of about $350{ }^{\circ} \mathrm{C}$; this may be attributed to the chemical equilibrium of reversible reactions which attained at higher reaction rates at high temperature. Beyond this temperature the increase in HDS efficiency is negligible. For example, at WHSV $=1.2$ the rate of increasing of $\mathrm{HDS} \%$ is $9 \%$ when the temperature raised from 310 to $330{ }^{\circ} \mathrm{C}$, while the increase in HDS is $1 \%$ when the temperature raised from 350 to $370{ }^{\circ} \mathrm{C}$. This may be attributed to the chemical equilibrium of reversible reactions which are achieved at higher temperatures.

\subsubsection{Influence of WHSV}

WHSV is a useful parameter in design and scale-up of continuous flow reactors. In the present study the selected WHSV values (1.2-3.6 $\mathrm{h}^{-1}$ ) were within the range of the values used in the industry (Kunda et al., 2003). The influence of the WHSV on HDS efficiency of a mixture of HCs is illustrated in Figure (6) for $\mathrm{CoNiMo} / \mathrm{Al}_{2} \mathrm{O}_{3}$ catalyst at the temperature and WHSV ranges $310-370{ }^{\circ} \mathrm{C}$ and $1.2-3.6 \mathrm{~h}^{-1}$ respectively at constant pressure $=50$ bars and $\left(\mathrm{H}_{2} / \mathrm{HC}\right)$ ratio of $200 \mathrm{vol} / \mathrm{vol}$. The selected WHSV values $\left(1.2-3.6 \mathrm{~h}^{-1}\right)$ were within the range of the values used in the industry (Kundu, 2006). 

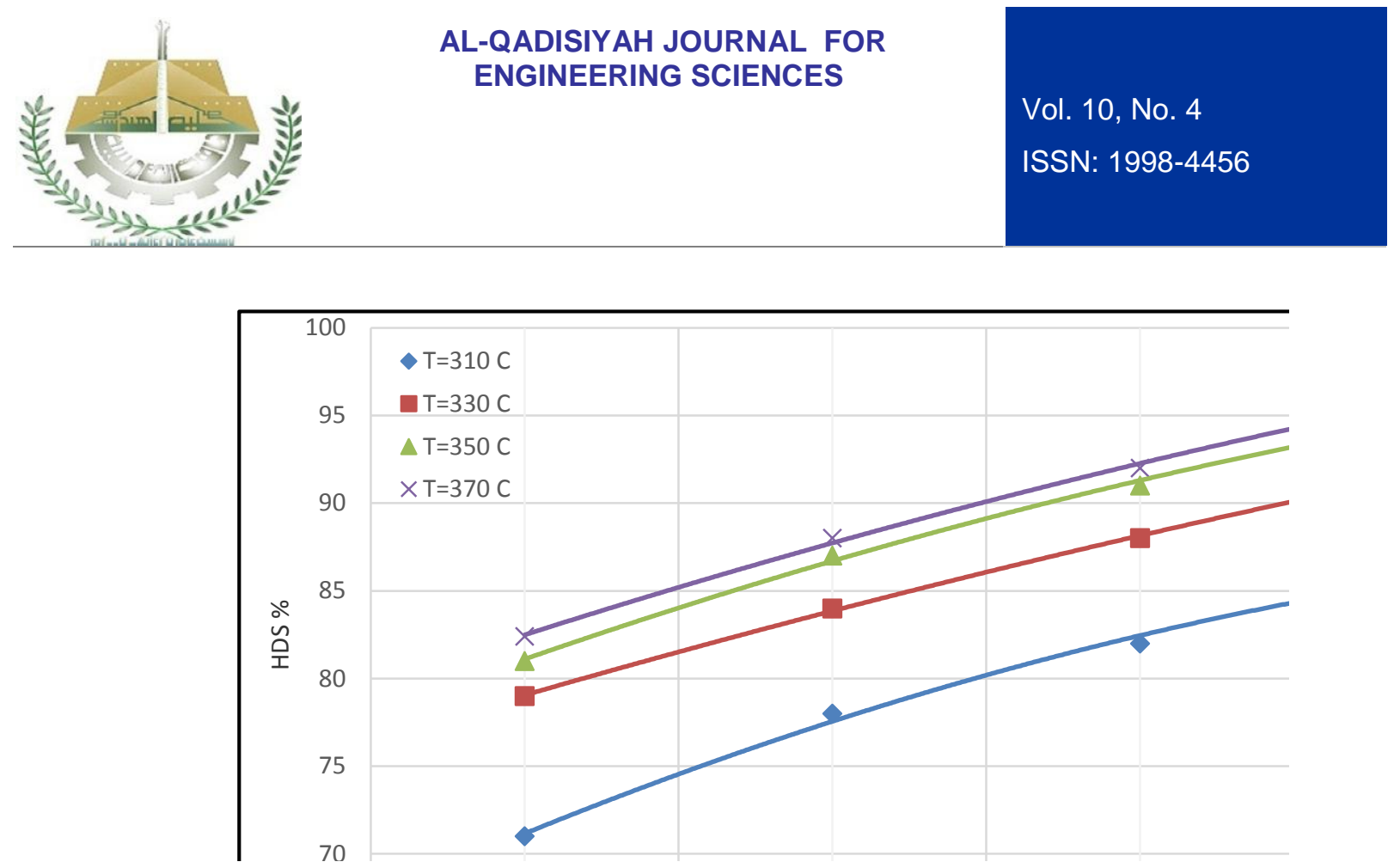

Figure (6): Effect of WHSV on HDS efficiency of a mixture of HCs at different reaction temperature at constant $\left(\mathrm{P}=50\right.$ bars and $\left(\mathrm{H}_{2} / \mathrm{HC}\right)$ ratio $\left.=200 \mathrm{vol} / \mathrm{vol}\right)$ for $\mathrm{CoNiMo} / \mathrm{Al}_{2} \mathrm{O}_{3}$.

Figure (6) shows that a decrease in WHSV results in an enhanced HDS efficiency. The sulfur content decreases and inversely the produced $\mathrm{H}_{2} \mathrm{~S}$ gas increases. At temperature $=350{ }^{\circ} \mathrm{C}$, HDS efficiency is 81 , 87,91 and $95.8 \%$ as the WHSV is $3.6,2.8,2$ and $1.2 \mathrm{~h}^{-1}$ respectively. It was observed that at constant temperature $=350{ }^{\circ} \mathrm{C}$ and pressure $=50$ bars, increasing WHSV from 1,2 to $3.6 \mathrm{~h}^{-1}$ decreased HDS $\%$ by $12.5 \%$. This may be attributed to the contact time between reactants and catalyst which increases as the WHSV decreases, HDS efficiency is increased correspondingly.

\subsubsection{Influence of pressure}

The influence of the pressure on HDS efficiency of a mixture of $\mathrm{HCs}$ is illustrated in Figure (7) for $\mathrm{NiCoMo} / \mathrm{Al}_{2} \mathrm{O}_{3}$ catalyst at the pressure and WHSV ranges $40-55$ bars and $1.2-3.6 \mathrm{~h}^{-1}$ respectively at $350{ }^{\circ} \mathrm{C}$ and $\left(\mathrm{H}_{2} / \mathrm{HC}\right)$ ratio of $200 \mathrm{vol} / \mathrm{vol}$.

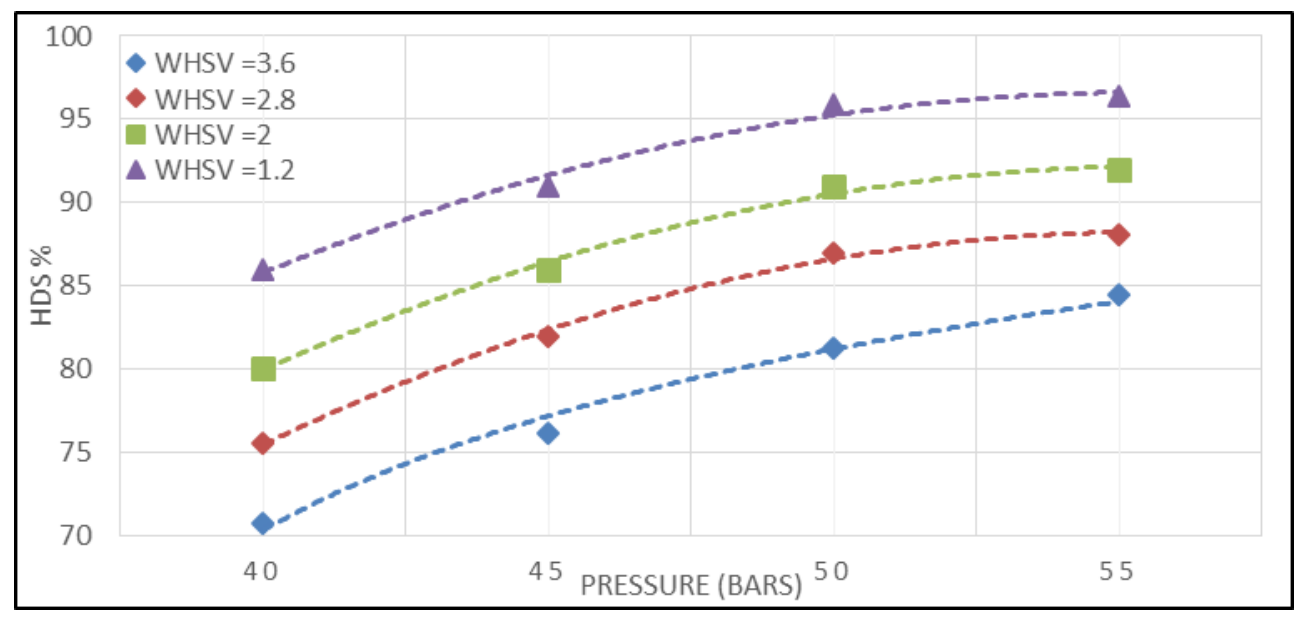

Figure (7): Variation of HDS \% against pressure at different WHSV at constant $\left(\mathrm{T}=350{ }^{\circ} \mathrm{C}\right.$ and $\mathrm{H}_{2}$-to-HC ratio $=200 \mathrm{vol} / \mathrm{vol})$ for $\mathrm{CoNiMo} / \mathrm{Al}_{2} \mathrm{O}_{3}$.

In Figure (6), HDS efficiency is enhanced by increasing the pressure, this enhance in HDS\% may be refer to the desulfurization of some refractory molecules (i.e., DBT) which proceeds only at very high pressures(Sidhartha ,2011). At WHSV=1.2, the HDS efficiency is $87.4,91,95.8$, and $96.4 \%$ when the 


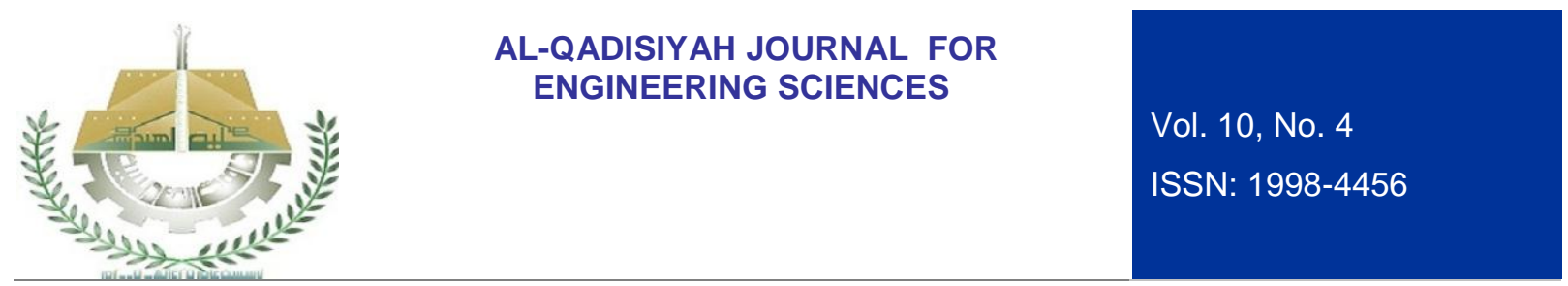

pressure is 40, 45, 50, and 55 respectively. Moreover, Figure (6) reported that when the pressure raised up from 50 to 55 bar the enhancement in the HDS efficiency is negligible. This could be due to the phenomenon of pores saturation which becomes effective when the pressure attained high values. This saturation reduces the effect of any increase in pressure on HDS improvement. Furthermore, Figures (5) and (7) revealed that the influence of temperature on sulfur removal is dominant over pressure.

\subsection{COMPARISON BETWEEN CONVENTIONAL AND PROPOSED METHODS}

\subsubsection{Yield analysis}

Table (5) shows the experimental results of the feed and product compositions for the proposed hydrotreating reactor. As indicated, sulfur removal of high molecular weight compounds increases as operating temperature increases and WHSV decreases. It is seen that at $T=330^{\circ} \mathrm{C}$, with various values of WHSV, the products composition kept constant which indicates that the conversion of high molecular compounds can be performed only at more severe conditions. However, it well known that Mild hydrocracking (MHC) takes place in the same time with $\mathrm{HDS}$ at the temperature range of $350^{\circ} \mathrm{C}$ to $370^{\circ} \mathrm{C}$. More conversion of high molecular weight compound to lower molecular weight compound is occurred at higher temperature and lower WHSV. Table (4) lists the results of distillation for product of proposed HDS.

\subsubsection{Comparison of product quality}

Figure (8) illustrates comparative results for yields of the proposed and traditional methods at optimal values of process variables. $\left(P=50\right.$ bars, $T=350{ }^{\circ} \mathrm{C}$, and WHSV $=1.2 \mathrm{~h}^{-1}$ ). As can be seen from Figure (7), the production of L.Naphtha, H.Naphtha, kerosene, and gas oil was almost the same for both methods. As indicated in Figure (8), there is a 1.6\% reduction in gas oil less than that of conventional method. However, kerosene, heavy naphtha, and light naphtha undergo increases of $0.6 \%, 0.75 \%$, and $2.75 \%$ respectively over these from conventional method. These results indicate that the quantity of fractions is almost the same for both methods.

Table (6) and Table (7) list the main properties of middle distillates yielded by traditional and proposed methods, respectively. This analysis was performed to detect any deviation in properties for fractions produced by the two methods. As can be seen from Table (6) and Table (7) that the results obtained confirmed the properties match of fractions yielded by the two methods. However, API for the fraction yielded by proposed method is somewhat higher than API of the same fractions yielded by traditional method, which suggests an upgrading in properties of these fractions.

Table (5): Yield analysis results.

\begin{tabular}{|c|c|c|c|c|c|}
\hline \multirow{3}{*}{ Temperature } & \multirow{3}{*}{ Lumps } & \multicolumn{4}{|c|}{ WHSV $\left(\mathrm{hr}^{-1}\right)$} \\
\cline { 3 - 6 } & & 0 & 2.8 & 2 & 1.2 \\
\cline { 3 - 6 } & & Feed (wt. \%) & \multicolumn{3}{|c|}{ Products (wt. \%) } \\
\hline \multirow{3}{*}{$330^{\circ} \mathrm{C}$} & $\mathrm{LN}$ & 4.96 & 4.96 & 4.96 & 4.97 \\
\cline { 2 - 6 } & $\mathrm{HN}$ & 9.28 & 9.28 & 9.28 & 9.29 \\
\cline { 2 - 6 } & Kerosene & 9.99 & 9.99 & 9.99 & 9.99 \\
\cline { 2 - 6 } & LGO & 16.60 & 16.60 & 16.60 & 16.58 \\
\hline \multirow{3}{*}{$350^{\circ} \mathrm{C}$} & $\mathrm{LN}$ & 4.96 & 4.97 & 5.00 & 5.10 \\
\cline { 2 - 6 } & HN & 9.28 & 9.29 & 9.30 & 9.35 \\
\cline { 2 - 6 } & Kerosene & 9.99 & 9.99 & 10.00 & 10.05 \\
\cline { 2 - 6 } & LGO & 16.60 & 16.58 & 16.53 & 16.32 \\
\hline
\end{tabular}




\section{AL-QADISIYAH JOURNAL FOR ENGINEERING SCIENCES}

Vol. 10 , No. 4

ISSN: $1998-4456$

\begin{tabular}{|c|c|c|c|c|c|}
\hline \multirow{3}{*}{$370^{\circ} \mathrm{C}$} & LN & 4.96 & 5.00 & 5.01 & 5.11 \\
\cline { 2 - 6 } & $\mathrm{HN}$ & 9.28 & 9.30 & 9.32 & 9.36 \\
\cline { 2 - 6 } & Kerosene & 9.99 & 10.00 & 10.02 & 10.05 \\
\cline { 2 - 6 } & LGO & 16.60 & 16.53 & 16.48 & 16.31 \\
\hline
\end{tabular}

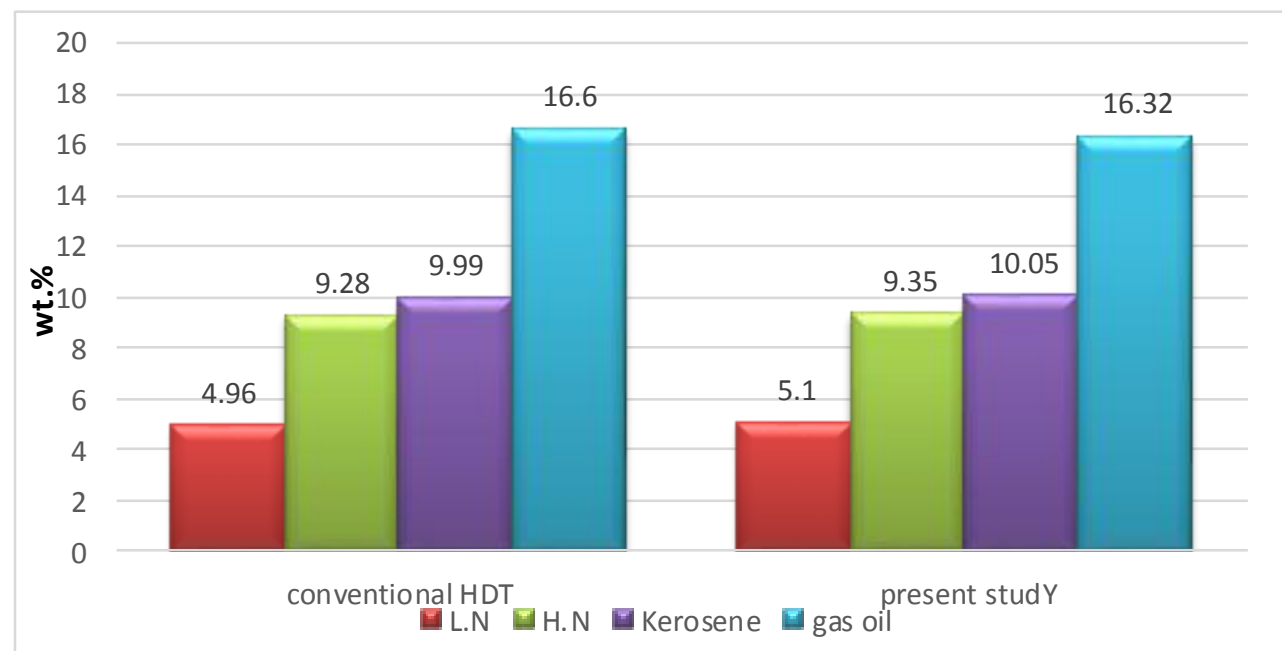

Figure (8): Percentage weights of middle distillates yielded by proposed and traditional method.

Table (6): Specification of distillate fractions yielded by traditional method.

\begin{tabular}{|c|c|c|c|c|}
\hline \multirow{2}{*}{ Property } & \multicolumn{4}{|c|}{ Distillate Fractions } \\
\cline { 2 - 5 } & L.Naphtha & H.Naphtha & Kerosene & L. gas Oil \\
\hline API@15.6 ${ }^{0} \mathrm{C}$ & 83.5 & 60.2 & 48.0 & 41.4 \\
\hline Sp.gr @ 15.6 ${ }^{0} \mathrm{C}$ & 0.6581 & 0.7381 & 0.788 & 0.8183 \\
\hline Distilled (vol.) & ${ }^{0} \mathrm{C}$ & ${ }^{0} \mathrm{C}$ & ${ }^{0} \mathrm{C}$ & ${ }^{0} \mathrm{C}$ \\
\hline I.B.P & 35 & 80 & 160 & 195 \\
\hline $5 \%$ & 38 & 88 & 172 & 225 \\
\hline $10 \%$ & 40 & 98 & 180 & 235 \\
\hline $20 \%$ & 48 & 106 & 185 & 252 \\
\hline $30 \%$ & 52 & 112 & 190 & 260 \\
\hline $40 \%$ & 56 & 118 & 195 & 268 \\
\hline $50 \%$ & 60 & 124 & 200 & 275 \\
\hline $60 \%$ & 65 & 130 & 205 & 285 \\
\hline $70 \%$ & 70 & 135 & 210 & 290 \\
\hline $80 \%$ & 75 & 140 & 215 & 295 \\
\hline $90 \%$ & 86 & 145 & 225 & 305 \\
\hline $95 \%$ & 98 & 152 & 235 & 315 \\
\hline Ep \% & 120 & 174 & 250 & 325 \\
\hline
\end{tabular}




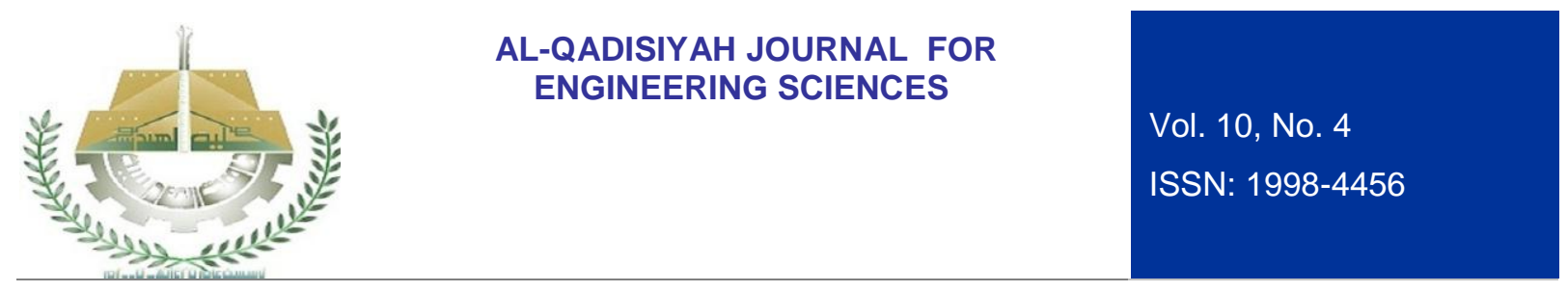

Table (7): Specification of distillate fractions yielded by proposed method

\begin{tabular}{|c|c|c|c|c|}
\hline \multirow{2}{*}{ Property } & \multicolumn{4}{|c|}{ Distillate Fractions } \\
\cline { 2 - 5 } & L.Naphtha & H.Naphtha & Kerosene & L. gas Oil \\
\hline API@15.6 ${ }^{\circ} \mathrm{C}$ & 84.4 & 62.7 & 48.7 & 40.5 \\
\hline Sp.gr @ 15.6 ${ }^{0} \mathrm{C}$ & 0.6553 & 0.7286 & 0.7852 & 0.8226 \\
\hline Distilled (vol.) & ${ }^{0} \mathrm{C}$ & ${ }^{0} \mathrm{C}$ & ${ }^{0} \mathrm{C}$ & ${ }^{0} \mathrm{C}$ \\
\hline I.B.P & 30 & 80 & 165 & 200 \\
\hline $5 \%$ & 36 & 90 & 170 & 220 \\
\hline $10 \%$ & 40 & 100 & 175 & 236 \\
\hline $20 \%$ & 45 & 108 & 182 & 258 \\
\hline $30 \%$ & 48 & 116 & 195 & 265 \\
\hline $40 \%$ & 54 & 122 & 198 & 270 \\
\hline $50 \%$ & 55 & 128 & 202 & 275 \\
\hline $60 \%$ & 62 & 132 & 206 & 280 \\
\hline $70 \%$ & 68 & 138 & 212 & 288 \\
\hline $80 \%$ & 75 & 142 & 218 & 295 \\
\hline $90 \%$ & 85 & 147 & 225 & 300 \\
\hline $95 \%$ & 94 & 155 & 230 & 312 \\
\hline Ep \% & 122 & 176 & 252 & 322 \\
\hline
\end{tabular}

\subsection{STATISTICAL ANALYSIS AND KINETICS MODELS}

The interaction of parameters, optimum operating conditions, and regression models for predicting the percent conversion of sulfur in HDS process to obtain optimum HDS \% are estimated using Analysis of Variance (ANOVA) technique. Two statistical tests (test of significance of factors and $R^{2}$ test) were used to evaluate how well the experimental data was represented by the models:

1- Test of significance of factors means that insignificant factors or interactions must be excluded from the model. Significance of the factors or the interactions is evaluated using $p$-value (probability value). When the $p$-value of a factor or an interaction is greater than 0.05 , then this factor or interaction is considered insignificant and can therefore be excluded from the final mathematical model.

2- $R^{2}$ test, a value that always falls between 0 and 1 , is the relative predictive power of a model. The closer to 1 the $R^{2}$ is the better the model represents the experimental observations. Adjusted $R^{2}$ is a modification of $R^{2}$, but unlike $R^{2}$ it only increases when the newly included factor(s) or interaction (s) are significant. Another quantity is predicted $R^{2}$. While $R^{2}$ indicates how well the model fits the experimental data at hand, predicted $\mathrm{R}^{2}$ indicates how well the model predicts responses for new observations.

Analysis of the experimental results was carried out using DESIGN-EXPERT 10.0.6.0 to optimize the considered operating conditions with respect to HDS \%. The factorial design method was used for planning the experiments, because of its reliability in finding the effects and interaction between the controlled variables ( $\mathrm{P}, \mathrm{T}$ and $\mathrm{WHSV})$ of the operating system.

Table (8): Independent variables with their coded and actual values

\begin{tabular}{|c|c|c|c|c|c|}
\hline Factor & Real symbol & Units & Minimum Limit & Maximum Limit & No. of levels (L) \\
\hline $\mathrm{X} 1$ & $\mathrm{P}$ & $\mathrm{bar}$ & 40 & 55 & 4 \\
\hline $\mathrm{X} 2$ & $\mathrm{~T}$ & ${ }^{\circ} \mathrm{C}$ & 310 & 370 & 4 \\
\hline $\mathrm{X} 3$ & WHSV & $\mathrm{hr}-1$ & 1.2 & 3.6 & 4 \\
\hline
\end{tabular}




\section{AL-QADISIYAH JOURNAL FOR ENGINEERING SCIENCES}

\section{Vol. 10 , No. 4}

ISSN: $1998-4456$

Regression analysis of experimental data generated Equation (2) which represents a polynomial related the objective function (i.e. \%HDS) to the studied operating variables with correlation coefficient $\left(R^{2}\right)=$ 0.9955; Adj. R-Squared $=0.9935$; and Pred. R-Squared $=0.9871$. The "Pred. $R^{2 "}$ is in reasonable agreement with the "Adj. $\mathrm{R}^{2 "}$ with difference less than 0.02 .

\section{$\%$ HDS $=-530.2264+11.2045 \mathrm{P}+1.8329 \mathrm{~T}-8.4586 \mathrm{WHSV}-5.5833 \times 10^{-3} \mathrm{P} \times \mathrm{T}+0.1458 \mathrm{P} \times \mathrm{WHSV}-$ $0.0104 \mathrm{~T}$ x WHSV $-.08887 \mathrm{P}^{2}-2.0471 \times 10^{-3} \mathrm{~T}^{2}-0.1075 \mathrm{WHSV}^{2}$

Equation (2) can be used to make predictions about the response for given levels of each factor. Here, the levels should be specified in the original units for each factor. The models predicted with reasonable accuracy the experimental results (with $R^{2}>0.99$ ). Figure (9) compares the Actual Value and Predicted Value of HDS\% Response.

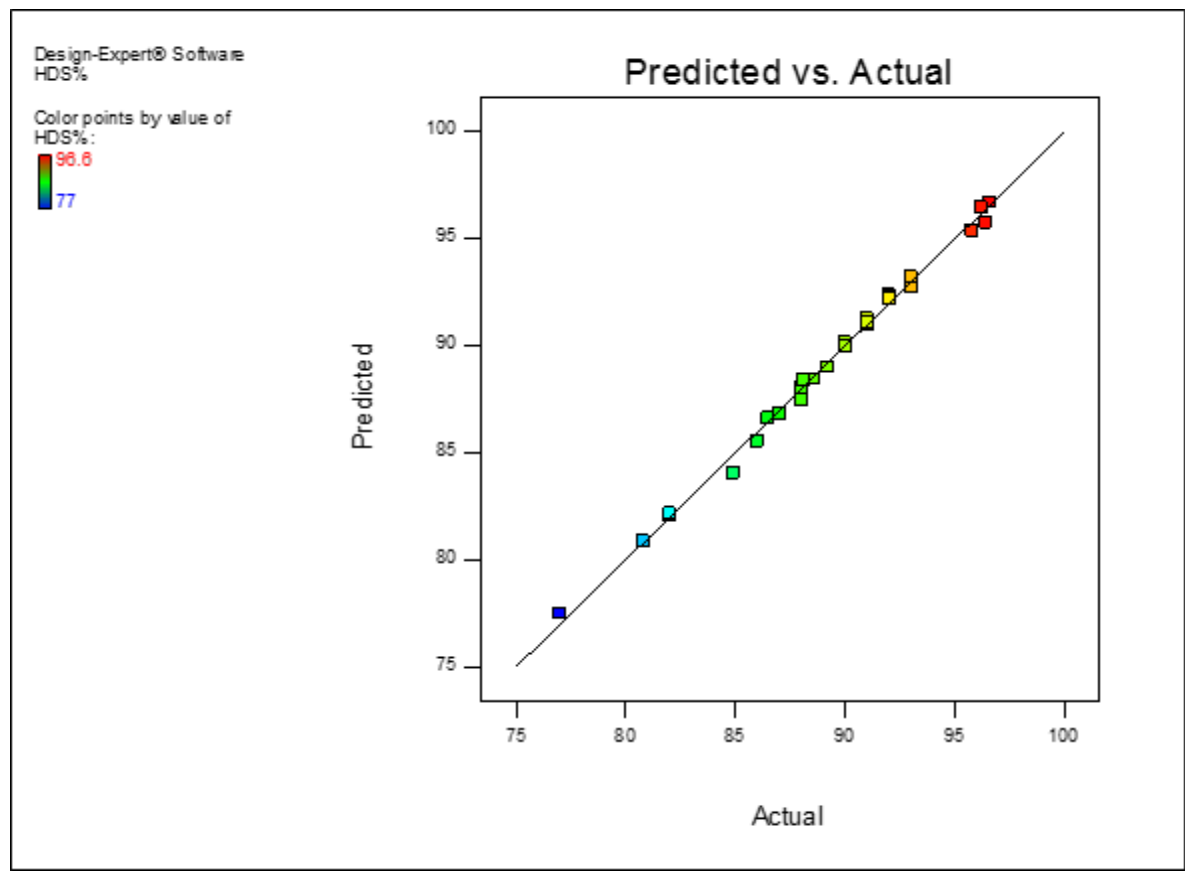

Figure (9): compares the Actual Value and Predicted Value of HDS\% Response.

The p-test was used to test the significance of factors and interactions between the parameters for HDS models. Table (9) lists the results of the $p$ - test.

Table (9): Results of test of the significance of factors and interactions for HDS models.

\begin{tabular}{|l|l|l|l|}
\hline \multicolumn{4}{|l|}{ ANOVA analysis for response surface quadratic model } \\
\hline Source & F- Value & p-value & \\
\hline Model & 513.09 & $<0.0001$ & Significance \\
\hline $\mathrm{P}$ & 1417.64 & $<0.0001$ & + \\
\hline $\mathrm{T}$ & 510.35 & $<0.0001$ & + \\
\hline WHSV & 2244.69 & $<0.0001$ & + \\
\hline $\mathrm{P}^{*} \mathrm{~T}$ & 26.52 & $<0.0001$ & + \\
\hline $\mathrm{P}^{*}$ WHSV & 28.94 & $<0.0001$ & + \\
\hline$T^{*}$ WHSV & 2.36 & 0.1392 & $*$ \\
\hline
\end{tabular}




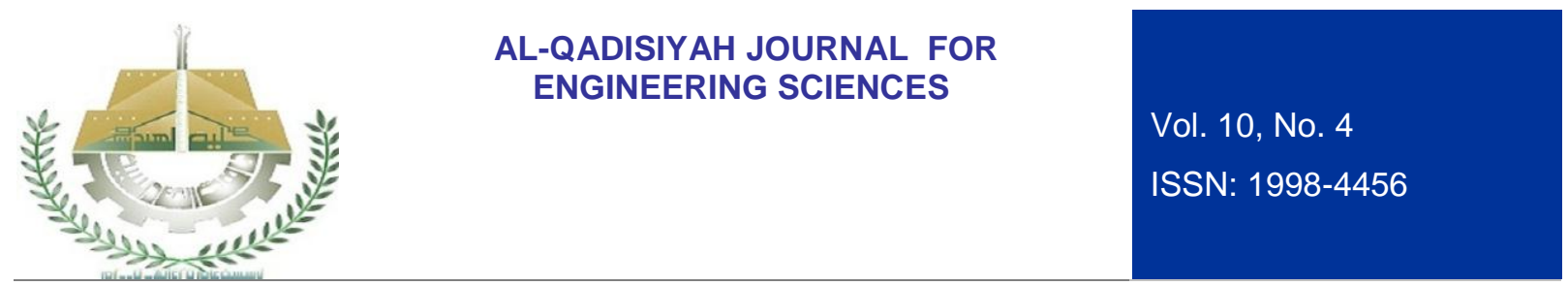

\begin{tabular}{|l|l|l|l|}
\hline $\mathrm{P}^{2}$ & 253.46 & $<0.0001$ & + \\
\hline $\mathrm{T}^{2}$ & 34.52 & $<0.0001$ & + \\
\hline WHSV $^{2}$ & 0.24 & 0.6265 & ${ }^{*}$ \\
\hline
\end{tabular}

+: significant; *: insignificant

Table (9) demonstrates the evaluated F-value and the corresponding $p$ values. The single-factor term represents a linear effect of the corresponding factor, while the two factors represent the interaction between the two factors. Additionally, the second order term represents a quadratic effect towards the response. The $p$ value serves as a tool to check the significance of each coefficient at a specified level of significance. The higher the $t$-value or the smaller the $p$ value, more significant the corresponding coefficient. Generally, a $p$ value of less than 0.05 is considered to be very significant and contributes largely towards the responses.

As observed in Table (9) , the terms $\mathrm{P}, \mathrm{T}, \mathrm{WHSV}, \mathrm{P} \times \mathrm{WHSV}, \mathrm{P}^{2}$, and $\mathrm{T}^{2}$ are significant model terms. However, the terms of values greater than 0.1000 are considered insignificant. In this case reduction of the terms T x WHSV, and WHSV ${ }^{2}$ may improve HDS model.

\subsubsection{Optimum operating conditions}

Based on the studied operating variables, the best values to obtain the optimum HDS\% are estimated using DESIGN-EXPERT 10.0.6.0 software. Figure (10) shows the location of the optimum conditions using the DESIGN-EXPERT software.

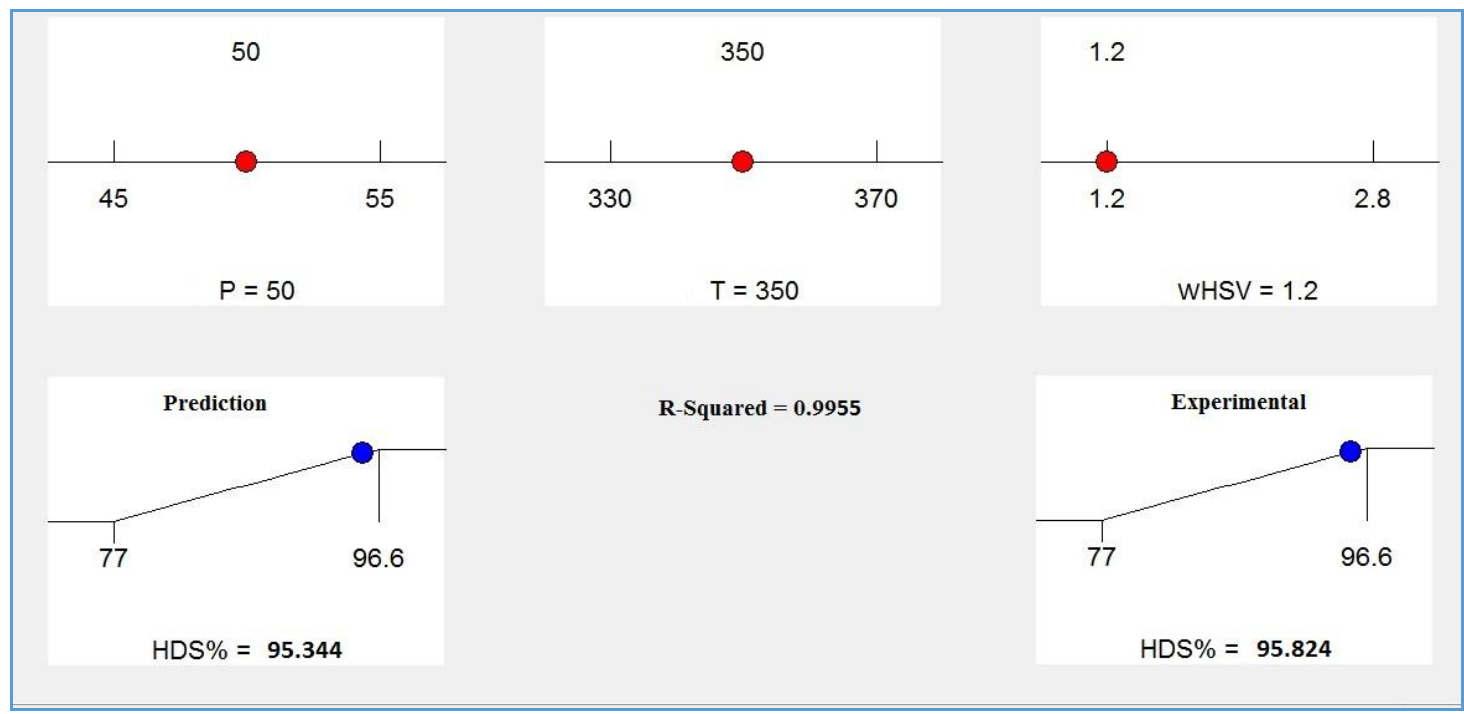

Figure (10): Best values of the studied operating conditions to obtain optimum HDS\%.

\section{CONCLUSIONS}

Simplification of the HDT system was the goal of all process and design engineers of the field. In the present work a single HDT reactor was proposed for HDS of a mixture of naphtha, kerosene, and gas oil produced from atmospheric fractionation unit at Al-Dora Refinery. Experimental results showed that temperature and pressure have a positive effect on process performance while weight hour space velocity gives a different trend. Results showed that the best values to obtain the optimum HDS\% are estimated using DESIGN-EXPERT 10.0.6.0 software $\left(350{ }^{\circ} \mathrm{C}\right.$, 50 bars, $1.2 \mathrm{~h}^{-1}$, and $\left.200 \mathrm{vol} / \mathrm{vol}\right)$, the 


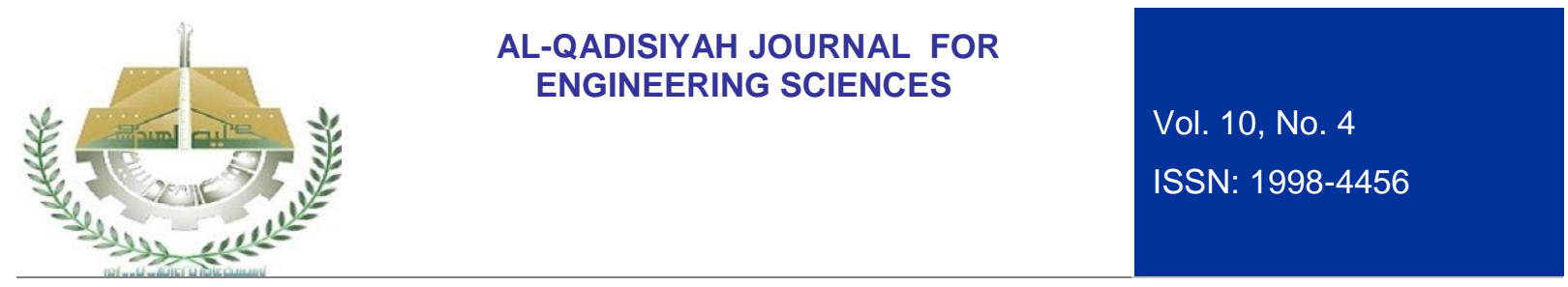

hydrodesulfurization (HDS) efficiency was 95.8\%. Maximum sulfur conversion of (95-96) \% was obtained at pressure range (50-55) bars. This increase in HDS efficiency may be attributed to the desulfurization of some refractory (i.e. DBT) molecules which proceeds only at very high pressures. Quantitative and qualitative analysis for the products from the proposed HDT method confirmed the feasibility and applicability of the method. the production of L.Naphtha, H.Naphtha, kerosene, and gas oil, there is a $1.6 \%$ reduction in gas oil while kerosene, heavy naphtha, and light naphtha increases of $0.6 \%, 0.75 \%$, and $2.75 \%$ respectively over these from conventional method.

According to Statistical analysis (i.e. p-values) the significance order of the independent variables on the maximum obtained HDS activity is operating pressure then reaction temperature However, the effect of Weight hour space velocity terms on HDS activity is less statistically significant. The obtane models predicted with reasonable accuracy the experimental results (with $R^{2}>0.99$ ).

\section{ACKNOWLEDGEMENT}

Researchers are thankful to the School of Chemical Engineering, University of Technology for assistance in completion of this work. The fund which has been awarded by the Petroleum Research and Development Center is highly appreciated.

\section{REFERENCES}

1. Abid M.F., Abdullah M.K., Ali S. M. (2017) "Experimental Study on Catalyst Deactivation by Nitrogen Compounds in a Hydroprocessing Reactor", Arab J Sci Eng, DOI 10.1007/s13369-017-2480-8.

2. Bej S. K., Dalai A. K., Adjaye J. (2001) "Comparison of hydrodenitrogenation of basic and nonbasic nitrogen compounds present in oil sands derived heavy gas oil", Energy and Fuels 15, 375-383.

3. Knudsen K.G. (2006) "Ultra deep desulfurization of diesel: how an understanding of the underlying kinetics can reduce investment costs", in: Book Chapter-10 in, Practical Advances in Petroleum Processing, Springer, Berlin.

4. Deng Z., Wang T., Zhanwen W. (2010) "Hydrodesulfurization of diesel in a slurry reactor", Chemical Engineering Science 65, 480-486.

5. Farag H. , Mochida I. (2012) "A comparative kinetic study on ultra-deep hydrodesulfurization of pretreated gas oil over nanosized MoS2, CoMo-sulfide, and commercial CoMo/Al $\mathrm{O}_{3}$ catalysts ", Journal of Colloid and Interface Science, 372(1):121-129.

6. Ferreira C., Tayakout-Fayolle M., Guibard I. , Lemos F. , Toulhoat H., Ribeiro F.R. (2014)

"Hydrodesulfurization and hydrodemetallization of different origin vacuum residues", new modeling approach, Fuel 129, 267-277.

7. Heinrich G., Kasztelan S. (2001), "Hydrotreating Conversion processes”, Paris, Technip, 533-573.

8. Klimov O.V. , Nadeina K.A. , Dik P.P. , Koryakina, G.I. , Kazakov M.O. , Budukva S.V. , Gerasimov E.Yu. , Prosvirin I.P. , Kochubey, D.I. , Noskov A.S. (2016), "CoNiMo/Al $\mathrm{O}_{3}$ catalysts for deep. hydrotreatment of vacuum gas oir", Catalysis Today 271, 56-63.

9. Kundu A., Nigam K.D.P., Duquenne A.M., Delmas H. (2003) ,"Recent developments in hydroprocessing reactions", Rev. Chem. Eng., 19: 531-605.

10. Majak Mapiour,(2010),"Effects of the operating variables on hydrotreating of heavy gas oil:

Experimental, modeling, and kinetic studies", University of Saskatchewan ,Department of Chemical and Biological Engineering, Fuel 89(9):2536-2543.

11. Lappas A. A., R. Budisteanu R., Drakaki K., Vasalos I.A. (1999) "Production of low aromatics and low sulfur diesel in a hydrodesulfurization (HDS) pilot plant unit", Global Nest: the Int. J. 1(1): 15-22.

12. Liu Y., Zou Y. (2013) ,"Effects of aromatic cycle oils on performance of residue hydrotreating", Korean J. Chem. Eng. 30(11), 1985-1989. 


\section{AL-QADISIYAH JOURNAL FOR ENGINEERING SCIENCES}

\section{Vol. 10 , No. 4}

ISSN: 1998-4456

13. Rana M.S., Rufino N., Jacques L. (2004). "Competitive effects of nitrogen and sulfur content on activity of hydrotreating CoMo/AI $\mathrm{O}_{3}$ catalysts: a batch reactor study", Catalysis Today 98, 67-74.

14. Sidhartha Mohanty ,(2011)," Effect of citric acid on hydrotreating activity of NiMo catalysts”, Masters of Science, Department of Chemical and Biological Engineering ,University of Saskatchewan.

15. SPEIGHT,(2010), "Fundamentals of Petroleum and Petrochemical Engineering", CHEMICAL INDUSTRIES, Taylor \& Francis Groupin the United States of America. 